\title{
Effects of operating parameters for dry reforming of methane: A short review
}

\author{
Muhammad Ayoub ${ }^{1,2}$, Chi Cheng Chong ${ }^{1,2}$, Asif Zamir ${ }^{l}$, Yoke Wang Cheng'2, Sarah Farrukh ${ }^{3}$, Salman Raza Naqvi ${ }^{3}$, Herma \\ Dina Setiabudi ${ }^{4}$, Nadia Riaz ${ }^{5}$, Naveed Ramzan ${ }^{6}$, \\ ${ }^{1}$ Department of Chemical Engineering, University Technologi PETRONAS, 32610 Seri Iskandar, Perak, Malaysia. \\ ${ }^{2}$ Center for biofuel and Biochemical Research (CBBR), Institute for Self-sustainable Building, 32610 Seri Iskandar, Perak, Malaysia. \\ ${ }^{3}$ Department of Chemical Engineering, National University of Science and Technology, Islamabad, Pakistan. \\ ${ }^{4}$ Faculty of Chemical and Natural Resources Engineering, Universiti Malaysia Pahang, 26300 Gambang, Kuantan, Pahang, Malaysia \\ ${ }^{5}$ Department of Environmental Sciences, COMSATS University Islamabad, Abbottabad Campus, Abbottabad, 22060, Pakistan \\ ${ }^{6}$ Department of Chemical Engineering, University of Engineering and Technology, G.T. Road, Lahore 54890, Pakistan.
}

\begin{abstract}
Dry reforming of methane (DRM) which also known as $\mathrm{CO}_{2}$ reforming of methane is a wellinvestigated reaction to serve as an alternative technique to attenuate the abundance of greenhouse gases $\left(\mathrm{CO}_{2}\right.$ and $\left.\mathrm{CH}_{4}\right)$. The syngas yielded is the main component for the liquid fuels and chemicals production in parallel with the fluctuating price of oil. Major researches were executed to seek for the well-suited catalysts before the commercialization of DRM can be realized. However, severe deactivation due to the carbon formation restricted the usage of promising Ni-based catalysts for DRM. Meanwhile, the deactivation on these catalysts can be associated with the operating conditions of DRM, which subsequently promoted the secondary reactions at different operating conditions. In fact, the parametric study could provide a benchmark for better understanding of the fundamental steps embodied in the $\mathrm{CH}_{4}$ and $\mathrm{CO}_{2}$ activation as well as their conversions. This review explores on the influences of the reaction operating parameters in term of the reaction temperatures, reactant partial pressures, feed ratios, and weight hourly space velocity (WHSV) on catalytic performance and carbon accumulation for the DRM.
\end{abstract}

\section{Introduction}

The past few decades have witnessed tremendous progress in the research on greenhouse gases $\left(\mathrm{CH}_{4}\right.$ and $\mathrm{CO}_{2}$ ) utilization. This utilization can ensure the continuity of the energy supply for the future generation, which can be applied in internal combustion engines or in the fuel cells to generate electricity while mitigating pollutant emissions [1]. On the other hand, synthesis gas (syngas, a mixture of $\mathrm{H}_{2}$ and $\mathrm{CO}$ ) is of paramount importance as a building block towards the generation of the praiseworthy chemicals and synthetic fuels by the means of Fischer-Tropsch Synthesis (FTS) [2, 3]. To date, even though methane steam reforming has achieved the commercial grade, the contribution of the primary component of greenhouse gases, $\mathrm{CO}_{2}$ prompted an urgent substitution over the existing reforming technology $[4,5]$. Owing to the capability to alleviate the $\mathrm{CO}_{2}$ gas release and transform into useful products, thereupon, dry reforming of methane (DRM) has been instigated as a prestigious replacement for syngas generations $[3,5,6]$. However, challenges related to the carbon accumulation which can be related to the natures of the catalysts and also the operating conditions of DRM have to be addressed before meeting the commercialization level of DRM.
Previously, researchers paid immense focus on the catalysts investigations on catalyst selection. Intriguingly, Ni-based catalysts have been acknowledged their vast prospects over DRM reaction due to its low cost, satisfactory catalytic performance as well as readily available $[3,7]$. In fact, the optimal catalytic activity for DRM reaction not only affected by the catalysts adopted, but also the parametric factors such as reaction temperature, reactant partial pressure, feed composition, weight hourly space velocity (WHSV) and reactor type. As far we are concerned, the operating conditions of DRM are indispensable for the kinetic studies as well as efficient reactor design [8].

Therefore, in-depth understanding of the parametric study over DRM is crucial. Thermodynamics studies indicated the DRM process requires a larger amount of energy to operate due to its endothermic nature. Previous review by Usman et al. [9] has been reported on the influence different types of catalysts, active metals, promoters, particle size and reactor selection on catalytic performance and carbon deposition on DRM. Meanwhile, the operating conditions of DRM reaction are also crucial in affecting the catalytic performance for various catalysts. In addition, there are many other review papers [10-14] focused on discussing strategies to remove carbonaceous deactivation of catalysts by relating to the role of catalytic properties

\footnotetext{
* Corresponding author: chicheng.chong@utp.edu.my
} 
affected by the types of supports, active metal, promoters used, metal loading effect, catalysts preparation methods as well as thermodynamics study. However, there is almost no literature focus on the comparison of the DRM operating conditions, which are also key factors affecting the reaction performance. Thus, the parametric effects due to variation in reaction temperature, reactant composition, WHSV and the reactor design, which have been reported in the previous literature are summarized in this review to impart better interpretation over the challenges for DRM technology.

\section{Effect of operating parameters}

\subsection{Reaction Temperature}

The promotion of the side decomposition of the reactants induced by the nature of the reactions and the catalysts used led a positive temperature influence on the reactants' conversions and product yields. DRM is inevitably accompanied with carbon formation and supported catalysts are prone to catalyst deactivation due to the carbon formed and metal sintering effect $[7,15]$. Thus, effect of operating temperature of DRM have been studied in numerous previous literatures to provide clear justification on the deactivation happened on DRM. Herein, Table 1 provides a list of the influence of reaction temperature on DRM.

In a study carried out by Omoregbe et al. [8], the catalytic activity of the $10 \% \mathrm{Ni} / \mathrm{SBA}-15$ over DRM were evaluated under the operating parameters of reaction temperatures $\left(650-750^{\circ} \mathrm{C}\right)$ at ambient pressure with varying $\mathrm{CH}_{4} / \mathrm{CO}_{2}$ feed ratios and partial pressure. Results (Fig. 1) indicated both $\mathrm{CO}_{2}$ and $\mathrm{CH}_{4}$ conversions increased and less fluctuated with increasing reaction temperature. This can be explained by the carbonaceous deposit removal by $\mathrm{CO}_{2}$ from the catalyst surface via reverse Boudouard reaction $\left(\mathrm{C}+\mathrm{CO}_{2} \rightarrow 2 \mathrm{CO}\right)$ which thermodynamically preferred at high reaction temperature of $700-750^{\circ} \mathrm{C}[16,17]$. A decline in the activity at $650^{\circ} \mathrm{C}$, was due to the $\mathrm{CH}_{4}$ decomposition reaction that produce carbon deposition resulted from the thermodynamically favoured at $650^{\circ} \mathrm{C}$.

In the meantime, Cao and co-researchers [18] optimized the operating conditions of DRM for carbon deposition elimination by using thermodynamic calculations to investigate the influence of various operating temperatures $\left(550-1200^{\circ} \mathrm{C}\right)$, on the $\mathrm{H}_{2} / \mathrm{CO}$ ratio and the carbon deposition. At constant pressure $(\mathrm{P}=0.1 \mathrm{MPa})$ and $\mathrm{CH}_{4} / \mathrm{CO}_{2}$ ratio (1.0), a reverse trend can be noticed with an increase in temperature ranged from $550-700^{\circ} \mathrm{C}$. The results also inferred that significant and severe carbon depositions were observed between $546^{\circ} \mathrm{C}$ and $703^{\circ} \mathrm{C}$, which can be ascribed to the secondary reactions of $\mathrm{CH}_{2}$ cracking and $\mathrm{CO}$ dissociation that are referred as the primary reactions devoting to coke deposition. The former was stimulated at $550^{\circ} \mathrm{C} \leq \mathrm{T} \leq$ $1000^{\circ} \mathrm{C}$ and $\mathrm{P} \leq 0.1 \mathrm{MPa}$, whereas the moderately exothermic latter reaction was enhanced at $\mathrm{T} \leq 700^{\circ} \mathrm{C}$ and $\mathrm{P} \geq 0.1 \mathrm{MPa}$. Meanwhile, the carbon deposits consumer, moderately endothermic $\mathrm{CO}_{2}$ gasification happened at $\mathrm{T} \geq 703{ }^{\circ} \mathrm{C}$. They also claimed that reducing the reaction pressure or reducing the $\mathrm{CH}_{4} / \mathrm{CO}_{2}$ mole ratio could possibly have switched the carbon free regime at a lower reaction temperature.
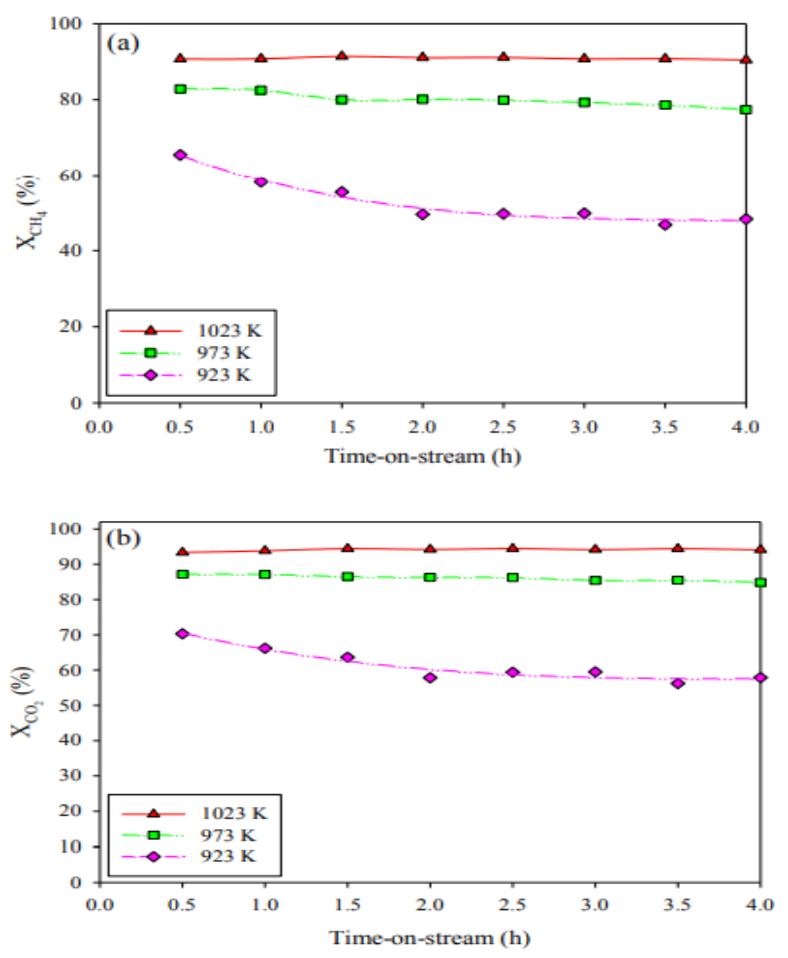

Fig. 1. Effect of reaction temperature on (a) $\mathrm{CH}_{4}$ and (b) $\mathrm{CO}_{2}$ conversions over $10 \% \mathrm{Ni} / \mathrm{SBA}-15$ catalyst. Adapted from [8].

Same goes to the study carried out by Sidik et al. [19] in which the reaction rate increases with the increased temperature due to the endothermic nature of DRM process $\left[\mathrm{CH}_{4}+\mathrm{CO}_{2} \rightarrow 2 \mathrm{CO}+2 \mathrm{H}_{2}\left(\Delta \mathrm{H}_{298 \mathrm{~K}}=+247\right.\right.$ $\left.\mathrm{kJ} \mathrm{mol}^{-1}\right)$ ] when using Ni-Co/MSN as catalyst [20]. Poor activity of the catalyst (low $\mathrm{CH}_{4}$ and $\mathrm{CO}_{2}$ conversions) can be observed at $\mathrm{T}<500^{\circ} \mathrm{C}$ (Fig. 2), yet approximately $\mathrm{CH}_{4}$ and $\mathrm{CO}_{2}$ conversions of $80 \%$ were reached at $\mathrm{T}>$ $700^{\circ} \mathrm{C}$. Analysis of variance (ANOVA) confirmed that most significant variable that affected the $\mathrm{CH}_{4}$ conversions was operating temperature. Besides, Zhang et al. (2003) [21] claimed that the composition of the reactant gases $\left(\mathrm{CO}_{2}\right.$ and $\left.\mathrm{CH}_{4}\right)$ decreased whilst the conversions of reactants were increased $(38-92 \%$; $28-$ $94 \%$ ) with the concurrent increased of water production when the temperature was raised $\left(450-800^{\circ} \mathrm{C}\right)$. The incline trend tended to reached plateau and then flattened out at $\mathrm{T}>700^{\circ} \mathrm{C}$. These results can be attributed to the hot spots formation at a high operating temperature in comparison with the bulk catalysts bed's average temperature.

Furthermore, Ayodele and co-workers [22] varied the reaction temperatures at the range of $650-750^{\circ} \mathrm{C}$ to investigate the feasibility of the $20 \mathrm{wt} \% \mathrm{Co} / 80$ $\mathrm{wt} \% \mathrm{Nd}_{2} \mathrm{O}_{3}$ catalyst over DRM. Under the feed ratio of $\mathrm{CH}_{4} / \mathrm{CO}_{2}=1$ and $\mathrm{T}=750^{\circ} \mathrm{C}, 62.7 \%$ and $82 \%$ were the maximum $\mathrm{CH}_{4}$ and $\mathrm{CO}_{2}$ conversions achieved, while the maximum $\mathrm{H}_{2}$ and $\mathrm{CO}$ products yield were $59.9 \%$ and $62.02 \%$, respectively. At $750{ }^{\circ} \mathrm{C}$, the $\mathrm{CH}_{4}$ conversion increased from $12.8 \%$ to $62.7 \%$ at $\mathrm{CH}_{4}: \mathrm{CO}_{2}$ of 0.1 to 
1.0, while the conversion of $\mathrm{CO}_{2}$ inclined from $50 \%$ to roughly $80 \%$ in the same $\mathrm{CH}_{4}: \mathrm{CO}_{2}$ range $\left(\mathrm{CH}_{4}\right.$ : $\mathrm{CO}_{2}=0.1$ ). Since the conversions recorded by both $\mathrm{CH}_{4}$ and $\mathrm{CO}_{2}$ were not similar, as opposed to their proposed methane dry reforming reaction (refers to Equation (1)), we posit that the $\mathrm{CH}_{4}$ may exhibit poorer affinity to the catalyst, most likely due to the presence of stronger basic sites that favoured $\mathrm{CO}_{2}$ adsorption as indicated by the TPD
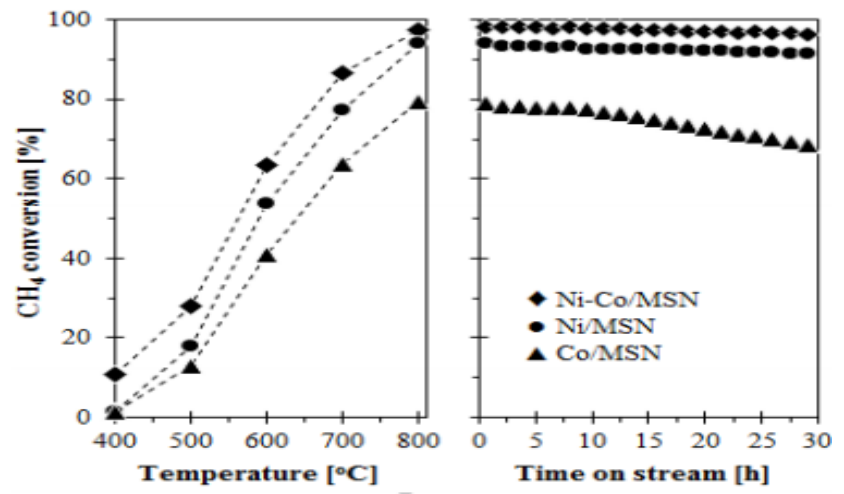

Fig. 2. Catalytic activity and stability of the Co/MSN, Ni/MSN and Ni-Co/MSN. Adapted from [19].

Meanwhile, Khavarian and Mohamed (2013) [23] suggested the $\mathrm{CH}_{4}$ and $\mathrm{CO}_{2}$ conversions over the synthesized MWCNTs were greatly influenced by the reaction temperatures within the range of $750-1000^{\circ} \mathrm{C}$ which also related to the endothermic nature of DRM. The catalyst exhibited high activity and stability with $82.68 \%$ conversion of $\mathrm{CH}_{4}$ at $950^{\circ} \mathrm{C}$, accompanied with insignificant activity loss. As such, the reaction rate of $\mathrm{CH}_{4}$ and $\mathrm{CO}_{2}$ over carbon nanotubes was affected significantly by the reaction temperature. Within the range of the reaction temperature studied, almost no coke formation over the catalyst surface and the syngas ratio was close to unity. The $\mathrm{CH}_{4}$ conversion marked a drastic rise from $41.24 \%$ at $750^{\circ} \mathrm{C}$ to $98.86 \%$ at $1000^{\circ} \mathrm{C}$. The $\mathrm{CO}_{2}$ conversion was slightly surpassed the $\mathrm{CH}_{4}$ conversion at the temperatures lower than $825^{\circ} \mathrm{C}$ but then excelled the $\mathrm{CO}_{2}$ conversion at higher temperatures. This can be correlated with the $\mathrm{CH}_{4}$ and $\mathrm{CO}_{2}$ adsorption and reaction rate competition over the MWCNTs with the temperature.

Furthermore, a thermodynamic equilibrium analysis for DRM was done by Nikoo and Amin [24]. Reaction temperatures were set at $200-1200^{\circ} \mathrm{C}$ to investigate the equilibrium conversions, product compositions and solid carbon formation at different $\mathrm{CO}_{2} / \mathrm{CH}_{4}$ ratios $(0.5-3)$ as well as reaction pressure $(101.3-2533.1 \mathrm{kPa})$. For all $\mathrm{CO}_{2} / \mathrm{CH}_{4}$ ratios, $\mathrm{CH}_{4}$ conversion almost drastically increased with increasing temperature up to $727^{\circ} \mathrm{C}$, meanwhile, for $\mathrm{CO}_{2}$ conversion, a gradual decline can be observed with temperature start from $300^{\circ} \mathrm{C}$ to about $550-600^{\circ} \mathrm{C}$. The decreasing trend for $\mathrm{CO}_{2}$ conversion can be mainly described by $\mathrm{CO}_{2}+2 \mathrm{H}_{2} \leftrightarrow \mathrm{C}+2 \mathrm{H}_{2} \mathrm{O}$. This exothermic reaction spontaneously occurs at low temperature but diminishes as the equilibrium constant decreases and reduces $\mathrm{CO}_{2}$ conversion. In addition, side reaction namely carbon dioxide methanation $\left(\mathrm{CO}_{2}+4 \mathrm{H}_{2} \leftrightarrow \mathrm{CH}_{4}+\right.$
$2 \mathrm{H}_{2} \mathrm{O}$ ) which is exothermic and promoted at a lower temperature $\left(300^{\circ} \mathrm{C}-650^{\circ} \mathrm{C}\right)$ also devoted to the same declining trend.

Table 1. Influence of reaction temperature on catalytic activity.

\begin{tabular}{|c|c|c|c|c|c|c|}
\hline \multirow{2}{*}{ Catalyst } & \multirow{2}{*}{$\begin{array}{c}\text { WHSV (L.g } \\
\left.{ }^{1} h^{-1}\right)\end{array}$} & \multirow{2}{*}{$\begin{array}{l}\mathrm{CH}_{4} / \\
\mathrm{CO}_{2} \\
\end{array}$} & \multirow{2}{*}{$\begin{array}{c}\mathrm{T} \\
\left({ }^{\circ} \mathrm{C}\right) \\
\end{array}$} & \multicolumn{2}{|c|}{$\mathrm{X}(\%)$} & \multirow[t]{2}{*}{ Ref. } \\
\hline & & & & $\mathrm{CO}_{2}$ & $\mathrm{CH}_{4}$ & \\
\hline \multirow{3}{*}{$\begin{array}{c}\mathrm{Ni} / \\
\text { SBA-15 }\end{array}$} & \multirow[t]{3}{*}{24} & \multirow[t]{3}{*}{1} & 650 & 70 & 64 & \multirow[t]{3}{*}{ [8] } \\
\hline & & & 700 & 87 & 83 & \\
\hline & & & 750 & 91 & 94 & \\
\hline \multirow{3}{*}{$\begin{array}{c}\mathrm{Ni}^{-} \\
\mathrm{Co} / \mathrm{MSN}\end{array}$} & \multirow[t]{3}{*}{15} & \multirow[t]{3}{*}{1} & 450 & - & 10 & \multirow[t]{3}{*}[18]{} \\
\hline & & & 550 & - & 62 & \\
\hline & & & 800 & - & 97 & \\
\hline \multirow{3}{*}{$\begin{array}{c}\mathrm{Co} / \\
\mathrm{Nd}_{2} \mathrm{O}_{3}\end{array}$} & \multirow[t]{3}{*}{30} & \multirow[t]{3}{*}{1} & 650 & 74 & 30 & \multirow[t]{3}{*}[22]{} \\
\hline & & & 700 & 78 & 38 & \\
\hline & & & 750 & 80 & 63 & \\
\hline \multirow{3}{*}{$\begin{array}{c}\text { Co-Mo- } \\
\mathrm{MgO} / \\
\text { MWCNTs }\end{array}$} & \multirow[t]{3}{*}{140} & \multirow[t]{3}{*}{1} & 750 & 17 & 25 & \multirow[t]{3}{*}[23]{} \\
\hline & & & 850 & 56 & 92 & \\
\hline & & & 950 & 90 & 98 & \\
\hline $15 \% \mathrm{Ni} / \mathrm{Al}$ & 30 & 1 & 600 & 67 & 45 & {$[25]$} \\
\hline${ }_{2} \mathrm{O}_{3}$ & & & 650 & 53 & 30 & \\
\hline & & & 700 & 83 & 58 & \\
\hline $30 \% \mathrm{Ni} / \mathrm{Al}$ & & & 600 & 45 & 7 & \\
\hline${ }_{2} \mathrm{O}_{3}$ & & & 650 & 63 & 5 & \\
\hline & & & 700 & 70 & 67 & \\
\hline $\mathrm{Pt} /$ & 7.2 & 1 & 500 & 45 & 33 & {$[21]$} \\
\hline $\mathrm{CeO}_{2} /$ & & & 600 & 65 & 55 & \\
\hline$\alpha-\mathrm{Al}_{2} \mathrm{O}_{3}$ & & & 700 & 80 & 76 & \\
\hline & & & 800 & 90 & 90 & \\
\hline $\mathrm{Ru} /$ & 18 & 1 & 635 & 81 & 73 & {$[26]$} \\
\hline $\mathrm{Al}_{2} \mathrm{O}_{3}$ & & & 735 & 94 & 92 & \\
\hline & & & 835 & 98 & 97 & \\
\hline LSRuZ & 18 & & 635 & 78 & 75 & \\
\hline & & & 735 & 95 & 93 & \\
\hline & & & 835 & 98 & 98 & \\
\hline $\mathrm{Ni} /$ & - & 1 & 200 & FBR & 21 & {$[27]$} \\
\hline $\mathrm{Al}_{2} \mathrm{O}_{3}$ & & & 300 & & 40 & \\
\hline $\mathrm{Ni} /$ & 18 & 1 & 700 & FBR & 57 & {$[28]$} \\
\hline $\mathrm{MgO}$ & & & 800 & & 73 & \\
\hline & & & 900 & & 92 & \\
\hline $\mathrm{Pt} /$ & 15 & 2 & 700 & FBR & 38 & {$[29]$} \\
\hline $\begin{array}{r}\mathrm{Mg}_{0.85} \\
\mathrm{Ni}_{0.15} \mathrm{O}\end{array}$ & & & 900 & & 97 & \\
\hline $\mathrm{MgCo}$ & 6 & 1 & 400 & FBR & 19 & {$[30]$} \\
\hline $\mathrm{Al}$ & & & 550 & & 65 & \\
\hline $\mathrm{Ni} /$ hydrot & - & 1 & 450 & FBR & 13 & [31] \\
\hline alcite- & & & 600 & & 60 & \\
\hline & & & 800 & & 95 & \\
\hline $\mathrm{Ni}-\mathrm{Co} /$ & 6 & 1 & 500 & FBR & 19 & {$[32]$} \\
\hline $\mathrm{La}_{2} \mathrm{O}_{3}-$ & & & 700 & & 75 & \\
\hline $\mathrm{Al}_{2} \mathrm{O}_{3}$ & & & 900 & & 94 & \\
\hline $\mathrm{Ni} /$ & 30 & 1 & 600 & FBR & 69 & [33] \\
\hline $\mathrm{La}_{2} \mathrm{Zr}_{2} \mathrm{O}_{7}$ & & & 650 & & 79 & \\
\hline & & & 700 & & 89 & \\
\hline
\end{tabular}

$\mathrm{T}=$ temperature, $\mathrm{X}=$ conversion.

Additionally, Schwengber at al. [25] performed DRM catalytic reaction tests by using $15 \% \mathrm{Ni} / \mathrm{Al}_{2} \mathrm{O}_{3}$ and $30 \% \mathrm{Ni} / \mathrm{Al}_{2} \mathrm{O}_{3}$ catalysts under the reaction temperature $\left(600-700^{\circ} \mathrm{C}\right.$ range). In general, increasing the reaction temperature in the DRM led to higher $\mathrm{H}_{2}$ yields and higher conversions of $\mathrm{CH}_{4}$ and $\mathrm{CO}_{2}$. Higher $\mathrm{CH}_{4}$ conversion (average of 59\%) was found to be at the $650^{\circ} \mathrm{C}$ by $30 \% \quad \mathrm{Ni} / \mathrm{Al}_{2} \mathrm{O}_{3}$ catalyst, while other conversions fall in the range of 30 to $40 \%$. The $\mathrm{H}_{2}$ yield was obtained at $700^{\circ} \mathrm{C}$ for both $15 \% \mathrm{Ni} / \mathrm{Al}_{2} \mathrm{O}_{3}$ and $30 \%$ $\mathrm{Ni} / \mathrm{Al}_{2} \mathrm{O}_{3}$ catalysts, but the formation rate dropped at the 4 th hour time-on-stream. These results showed that not only complete DRM occurred, but also other undesired reactions. The results proposed the co-existence of secondary reactions, which included reverse water-gas shift reaction $\left(\mathrm{CO}+\mathrm{H}_{2} \mathrm{O} \leftrightarrow \mathrm{CO}_{2}+\mathrm{H}_{2}\right)$, Boudouard reaction $\left(2 \mathrm{CO} \leftrightarrow \mathrm{C}+\mathrm{CO}_{2}\right)$ and $\mathrm{CO}$ reduction $\left(\mathrm{CO}+\mathrm{H}_{2}\right.$ 
$\leftrightarrow \mathrm{C}+\mathrm{H}_{2} \mathrm{O}$ ) that led to coke formation, low product yield and low reactants' conversions [34, 35].

After all, coke accumulations are the main contributor over the catalysts deactivation which leading to severe reactor tubing blockage and physical disintegration of the catalyst framework. This circumstance was evidenced to have close connection on the reaction temperature conducted as DRM reaction was inevitably accompanied by numerous side reactions. Due to the endothermic nature of the reaction, high temperature $\left(>750^{\circ} \mathrm{C}\right)$ is the main accomplishment to attenuate coke deposition.

\section{$2.2 \mathrm{CO}_{2}$ and $\mathrm{CH}_{4}$ partial pressure}

Owing to the vital role of reactants partial pressures on DRM on providing the quantities of reactants, a number of the reported papers are dedicated to elucidate the relationship between the reactants $\left(\mathrm{CO}_{2}\right.$ and $\left.\mathrm{CH}_{4}\right)$ partial pressure on the product yield and carbon deposition over DRM. Appropriate $\mathrm{CO}_{2}$ and $\mathrm{CH}_{4}$ partial pressures can minimize the happening of secondary reactions that were known to be main culprits for coke formation and catalyst deactivation. Table 2 summarizes the comparison study on the effect of reactants partial pressure on the catalytic performance over DRM.

Omoregbe et al. [8] reported on the DRM activity over $10 \% \mathrm{Ni} / \mathrm{SBA}-15$ catalyst at feed partial pressure of $20-60 \mathrm{kPa}$ (Fig. 3). When $\mathrm{CO}_{2}$ partial pressure $\left(\mathrm{P}_{\mathrm{CO}_{2}}\right)$ was increased, an increasing trend was observed for $\mathrm{CH}_{4}$ conversion, whilst $\mathrm{CO}_{2}$ conversion showed a substantial decline and exhibited an optimum performance at $\mathrm{P}_{\mathrm{CO}_{2}}=$ $30-50 \mathrm{kPa}$. The incline trend for $\mathrm{CH}_{4}$ conversion with increasing of $\mathrm{P}_{\mathrm{CO} 2}(20-60 \mathrm{kPa})$ was credited to the escalating intermediate by-product, $\mathrm{H}_{2} \mathrm{O}$ formation by RWGS reaction $\left(\mathrm{CO}_{2}+\mathrm{H}_{2} \rightarrow \mathrm{CO}+\mathrm{H}_{2} \mathrm{O}\right)$ which promoted $\mathrm{CH}_{4}$ steam reforming $\left(\mathrm{CH}_{4}+\mathrm{H}_{2} \mathrm{O} \rightleftharpoons \mathrm{CO}+\right.$ $3 \mathrm{H}_{2}$ ) as well. On the contrary, the considerable decline of $\mathrm{CO}_{2}$ conversion with rising $\mathrm{P}_{\mathrm{CO} 2}(20-60 \mathrm{kPa})$ was owing to the superabundance of $\mathrm{CO}_{2}$ and inadequate quantity of $\mathrm{CH}_{4}$ to act as limiting reactant for transforming $\mathrm{CO}_{2}$-rich feed composition [24, 36]. Furthermore, the drop in $\mathrm{CO}_{2}$ conversion with rising $\mathrm{P}_{\mathrm{CO} 2}$ also can be linked to the active $\mathrm{Ni}^{0}$ metallic site oxidation at the catalyst surface to $\mathrm{NiO}\left(\mathrm{Ni}+\mathrm{CO}_{2} \rightarrow\right.$ $\mathrm{NiO}+\mathrm{CO})$ in excess $\mathrm{CO}_{2}$ circumstance. However, the rising in the $\mathrm{P}_{\mathrm{CH} 4}(20-60 \mathrm{kPa})$ remarkably decreased both the reactants conversions, which was due to the increased carbon formation rate along with the occurrence via $\mathrm{CH}_{4}$ cracking $\left(\mathrm{CH}_{4} \rightarrow \mathrm{C}+2 \mathrm{H}_{2}\right)$ in $\mathrm{CH}_{4}$ rich feed [32]. Furthermore, $\mathrm{CH}_{4}$ decomposition was easily facilitated in the $\mathrm{CH}_{4}$-excess environment further enhance the decomposition rate and promoting carbon deposition $\lceil 4\rceil$.

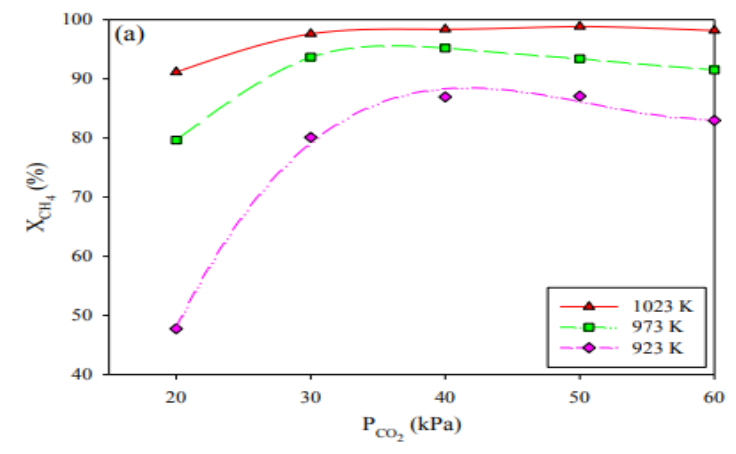

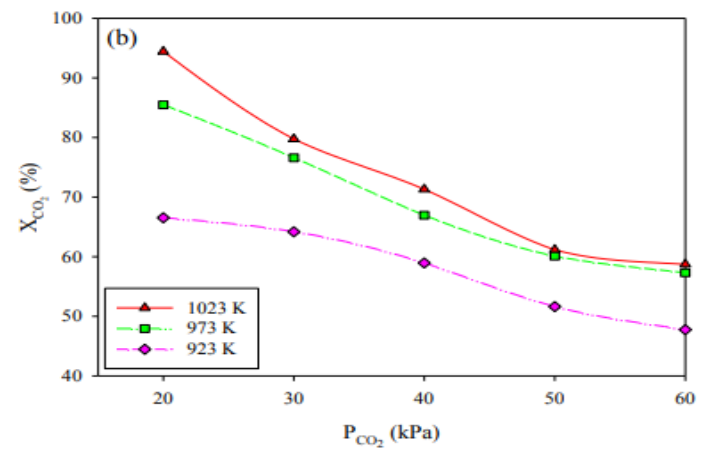

Fig. 3. Effect of $\mathrm{CO}_{2}$ partial pressure on (a) $\mathrm{CH}_{4}$, and (b) $\mathrm{CO}_{2}$ conversions over $10 \% \mathrm{Ni} / \mathrm{SBA}-15$ catalyst at temperature range of $650-750{ }^{\circ} \mathrm{C}$. Adapted from [8].

Likewise, Cao et al. [18] found that the reactants partial pressure reaction also affected the carbon formation rate during DRM. Results indicated that carbon deposition decreased when the partial pressures varied from 0.05 to $5 \mathrm{MPa}$ at $1200^{\circ} \mathrm{C}$. This finding was due to the $\mathrm{CO}$ dissociation $\left(2 \mathrm{CO} \rightleftharpoons \mathrm{C}+\mathrm{CO}_{2}\right)$ to form carbon was inhibited as the partial pressure increased, thus the carbon formation tendency shifted to higher temperature region $[18,37]$. Therefore, it would be preferable to yield syngas suitable for the long-chain hydrocarbons synthesis at high pressure, as post syngas compression by using high $\mathrm{CO}$ content is not a technically liable mission. Another previous literature reported by Ayodele and co-researchers (2017) [22] also found that reactants consumption rates increased proportionally with the increase in pressure $(5-50 \mathrm{kPa})$ when $\mathrm{Co} / \mathrm{Nd}_{2} \mathrm{O}_{3}$ was employed as catalyst according to the proposed Langmuir-Hinshelwood kinetic mechanism.

Furthermore, Nikoo and Amin (2011) [24] investigated on the effect of system pressure on $\mathrm{CH}_{4}$ and $\mathrm{CO}_{2}$ conversions, main products distribution and $\mathrm{H}_{2} / \mathrm{CO}$ ratio at $900{ }^{\circ} \mathrm{C}, \mathrm{CO}_{2} / \mathrm{CH}_{4}$ ratio of $1 . \mathrm{CO}_{2}$ and $\mathrm{CH}_{4}$ conversions were always excelled at lower pressures than those at higher pressures during reaction temperature at $900^{\circ} \mathrm{C}$. This proposes that at such a high temperature, greater pressures can impede the effect of temperature on increased reactant conversion. These decreased trends can be expressed by the endothermic trait of CRM. Besides, $\mathrm{CH}_{4}$ decomposition $\left(\mathrm{CH}_{4} \rightarrow \mathrm{C}+\right.$ $\left.2 \mathrm{H}_{2}\right)$ and $\mathrm{CO}$ disproportionation $\left(2 \mathrm{CO} \rightarrow \mathrm{CO}_{2}+\mathrm{C}\right)$ facilitate in lowering $\mathrm{CH}_{4}$ and $\mathrm{CO}_{2}$ conversions, as well as obstructing $\mathrm{CO}$ and $\mathrm{H}_{2}$ formation at the higher pressures. Another research done by Ayodele et al. (2015) [38] investigated on the influences of reactants' $\left(\mathrm{CH}_{4}\right.$ and $\left.\mathrm{CO}_{2}\right)$ partial pressures on the catalytic performance of the ceria-supported cobalt catalyst. The experiment was conducted by maintaining the partial pressure of one reactant constant at $50 \mathrm{kPa}$ and varied the other reactant pressure between $5-50 \mathrm{kPa}$ and vice versa at reaction temperatures of $650-750^{\circ} \mathrm{C}$. The highest conversion of $\mathrm{CH}_{4}$ and $\mathrm{CO}_{2}$ were acquired to be 78 and $80 \%$ at $\mathrm{CH}_{4}$ and $\mathrm{CO}_{2}$ partial pressure of 45 and $25 \mathrm{kPa}$, respectively. Syngas ratio of 1.0 was yielded at $\mathrm{CH}_{4}$ partial pressure of $40 \mathrm{kPa}$. They also expressed that catalysts with basic support (electron-rich surface) such as ceria could improve the acidic gas adsorption such as 
$\mathrm{CO}_{2}$. In the region of low partial pressure of $\mathrm{CO}_{2}$, due to the prevalence of excess $\mathrm{CH}_{4}$ and lack of $\mathrm{CO}_{2}$, most likely, $\mathrm{CH}_{4}$ underwent catalytic decomposition into $\mathrm{C}$ and $\mathrm{H}_{2}$. Consequently, the reverse Boudouard reaction is favored leading to high conversion of $\mathrm{CO}_{2}$.

In a nutshell, neither $\mathrm{CO}_{2}$ nor $\mathrm{CH}_{4}$ surplus environment can escaped from the co-occurrence of the secondary reactions that arose depends on the supply of the reactant gases. Thereupon, the optimal partial pressures for reactant gases varied with distinct catalysts adopted as well as other operating conditions.

Table 2. Influence of $\mathrm{CO}_{2}$ and $\mathrm{CH}_{4}$ partial pressure on catalytic activity.

\begin{tabular}{|c|c|c|c|c|c|c|c|c|}
\hline \multirow[t]{2}{*}{ Catalyst } & \multirow{2}{*}{$\begin{array}{c}\mathrm{T} \\
\left({ }^{\circ} \mathrm{C}\right)\end{array}$} & \multirow{2}{*}{$\begin{array}{l}\mathrm{CO}_{2} \\
/ \mathrm{CH}_{4}\end{array}$} & \multirow{2}{*}{$\begin{array}{c}\text { W } \\
\left(\mathrm{L} \cdot \mathrm{g}^{-}\right. \\
\left.{ }^{1} \mathrm{~h}^{-1}\right)\end{array}$} & \multicolumn{2}{|c|}{$\mathrm{P}(\mathrm{kPa})$} & \multicolumn{2}{|c|}{$\mathrm{X}(\%)$} & \multirow[t]{2}{*}{ Ref. } \\
\hline & & & & $\mathrm{CO}_{2}$ & $\mathrm{CH}_{4}$ & $\mathrm{CO}_{2}$ & $\mathrm{CH}_{4}$ & \\
\hline \multirow{6}{*}{$\begin{array}{c}\mathrm{Ni} / \\
\text { SBA-15 }\end{array}$} & \multirow[t]{6}{*}{750} & \multirow[t]{6}{*}{1} & \multirow[t]{6}{*}{24} & 20 & 20 & 95 & 90 & \multirow[t]{6}{*}[8]{} \\
\hline & & & & 40 & 20 & 73 & 97 & \\
\hline & & & & 60 & 20 & 64 & 96 & \\
\hline & & & & 20 & 20 & 92 & 90 & \\
\hline & & & & 20 & 40 & 84 & 56 & \\
\hline & & & & 20 & 60 & 78 & 40 & \\
\hline \multirow{6}{*}{$\begin{array}{c}\mathrm{Co} / \\
\mathrm{CeO}_{2}\end{array}$} & \multirow[t]{6}{*}{750} & \multirow[t]{6}{*}{1} & \multirow[t]{6}{*}{30} & 10 & 50 & 93 & 62 & \multirow[t]{6}{*}{ [38] } \\
\hline & & & & 30 & 50 & 87 & 75 & \\
\hline & & & & 50 & 50 & 70 & 73 & \\
\hline & & & & 50 & 10 & 37 & 35 & \\
\hline & & & & 50 & 30 & 64 & 48 & \\
\hline & & & & 50 & 45 & 84 & 62 & \\
\hline
\end{tabular}

$\mathrm{T}=$ temperature, $\mathrm{W}=\mathrm{WHSV}, \mathrm{X}=$ conversion.

\section{3. $\mathrm{CH}_{4} / \mathrm{CO}_{2}$ ratio}

According to the stoichiometric equation of DRM $\left(\mathrm{CO}_{2}\right.$ $+\mathrm{CH}_{4} \rightarrow 2 \mathrm{CO}+2 \mathrm{H}_{2}$ ), the $\mathrm{CO}_{2} / \mathrm{CH}_{4}=1$ case represents the stoichiometric oxidant supply of reactants. Since the role of $\mathrm{CO}_{2}$ in DRM is similar to the oxidant in combustion, $\mathrm{CO}_{2} / \mathrm{CH}_{4}$ with values less or greater than 1 represent the oxidant-lean and oxidant-rich cases, respectively. Thus, investigations on the $\mathrm{CH}_{4} / \mathrm{CO}_{2}$ ratio using different catalysts for DRM have been reported and compared as well in Table 3. Intriguingly, the results obtained by Cao et al. (2017) [18] evidenced that the $\mathrm{CH}_{4} / \mathrm{CO}_{2}$ mole ratio was the key factor to adjust $\mathrm{H}_{2} / \mathrm{CO}$ mole ratio, rather than adjusting the reaction pressure. Moreover, carbon formation decreased as $\mathrm{CH}_{4} / \mathrm{CO}_{2}$ mole ratio decreased, which indicates that reaction $\mathrm{CH}_{4}$ decomposition $\left(\mathrm{CH}_{4} \rightarrow \mathrm{C}+2 \mathrm{H}_{2}\right)$ was promoted to eliminate carbon formation with larger $\mathrm{CH}_{4} / \mathrm{CO}_{2}$ mole ratio for the whole temperature range. The statement was only valid for the operating temperature $>900^{\circ} \mathrm{C}$, meanwhile changing pressure could be used as an alternative option at operating temperature $<900^{\circ} \mathrm{C}$ for adjustment of $\mathrm{H}_{2} / \mathrm{CO}$ mole ratio as compared to varying $\mathrm{CH}_{4} / \mathrm{CO}_{2}$ mole ratio. According to the stoichiometric equation of $\mathrm{CRM}\left(\mathrm{CO}_{2}+\mathrm{CH}_{4} \rightarrow\right.$ $\left.2 \mathrm{CO}+2 \mathrm{H}_{2}\right)$, the $\mathrm{CO}_{2} / \mathrm{CH}_{4}=1$ case represents the stoichiometric oxidant supply of reactants. Since the role of $\mathrm{CO}_{2}$ in DRM is similar to the oxidant in combustion, $\mathrm{CO}_{2} / \mathrm{CH}_{4}$ with values less or greater than 1 represent the oxidant-lean and oxidant-rich cases, respectively. Chein et al. (2017) [39] implied that at the oxidant-rich condition in which the $\mathrm{CO}_{2}$ supply was excessive, $\mathrm{CH}_{4}$ conversion can be further improved as compared to the lower $\mathrm{CO}_{2}$ conversion results for the oxidant-rich case.
Under the same $\mathrm{CH}_{4}$ supply but less than the stoichiometric amount $\mathrm{CO}_{2}$ supply, less $\mathrm{CO}$ can be produced with excessive $\mathrm{CO}_{2}$ supply, since $\mathrm{CO}$ is one of the product elements [24].

Meanwhile, the $\mathrm{CH}_{4}$ conversion increased gradually with the increase of $\mathrm{CO}_{2}: \mathrm{CH}_{4}$ ratio from 1 to 5 as suggested by Sidik et al. (2016) [19] (Fig. 4). This observation implied that the $\mathrm{CO}_{2}$ has a positive impact on the $\mathrm{CH}_{4}$ conversion as it can act as an active oxidant [38]. This result could also be interpreted through the disproportionation reaction by the Le Chatelier's principal which explained that the surpass $\mathrm{CO}_{2}$ could enhance the amount of $\mathrm{CH}_{4}$ being converted to $\mathrm{CO}$ and $\mathrm{H}_{2}$. Besides, the stoichiometric effects of feed ratio on DRM to produce $\mathrm{H}_{2}$ and $\mathrm{CO}$ also examined by Osazuwa and Cheng (2017) [40] using three different stoichiometric feed ratios $\left(\mathrm{CO}_{2} / \mathrm{CH}_{4}=0.5,1,2\right)$ at temperature of $750^{\circ} \mathrm{C}$. At $\mathrm{CO}_{2} / \mathrm{CH}_{4}$ ratio of 0.5 where $\mathrm{CO} 2$ was the limiting reagent, $66 \% \mathrm{CH}_{4}$ conversion was achieved. When DRM was carried out at equimolar feed ratio $\left(\mathrm{CO}_{2} / \mathrm{CH}_{4}=1\right)$, the highest $\mathrm{CH}_{4}$ conversion was marked at $84 \%$ due to the exact matching with the stoichiometry ratio. Moreover, an increase in feed ratio from 0.5 to 1.0 witnessed a noticeable rise in the $\mathrm{H}_{2}$ production from $45 \%$ to $60 \%$. Moreover, the reverse gas shift $\left(\mathrm{CO}_{2}+\mathrm{H}_{2} \rightarrow \mathrm{CO}+\mathrm{H}_{2} \mathrm{O}\right)$ uses up the $\mathrm{H}_{2}$ produced, thus leading to a drop in $\mathrm{H}_{2}$ yield.
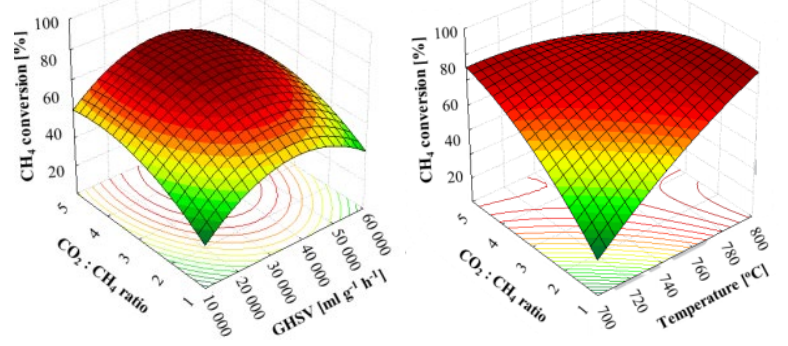

Fig. 4. Response surface plot of the combined (a) $\mathrm{CO}_{2}: \mathrm{CH}_{4}$ ratio and GHSV, (b) $\mathrm{CO}_{2}: \mathrm{CH}_{4}$ ratio and reaction temperature. Adapted from [19].

In addition, the effect of varying the feed molar ratios of $\mathrm{CO}_{2}: \mathrm{CH}_{4}$ on the conversions and product selectivity was investigated over the catalyst $\mathrm{Pt}$ $(8 \%) / \mathrm{CeO}_{2}(20 \%) / \alpha-\mathrm{Al}_{2} \mathrm{O}_{3}$ in a range of feed molar ratios $\left(\mathrm{CO}_{2}: \mathrm{CH}_{4}\right)$ from 1.0: 3.0 to $3.0: 1.0$ at $650^{\circ} \mathrm{C}$ were reported by Zhang et al. (2003) [21]. The $\mathrm{CH}_{4}$ conversion was found to increase with the increment of $\mathrm{CO}_{2}: \mathrm{CH}_{4}$ ratio, while the $\mathrm{CO}_{2}$ conversion decreased. The secondary reaction between $\mathrm{CO}_{2}$ and $\mathrm{H}_{2}$ took place when $\mathrm{CO}_{2}$ was in excess to produce the by-products, thus resulted in the decrease in $\mathrm{H}_{2}$ : $\mathrm{CO}$ ratio in the product. This demonstrated that the reforming reaction was inactive while accompanied with the reverse watergas shift reaction $\left(\mathrm{CO}_{2}+\mathrm{H}_{2} \rightarrow \mathrm{CO}+\mathrm{H}_{2} \mathrm{O}\right)$. Gaur et al. (2012) [26] studied the effect of the $\mathrm{CH}_{4} / \mathrm{CO}_{2}$ feed ratio $(0.5,1,2)$ on $\mathrm{La}_{1.97} \mathrm{Sr}_{0.03} \mathrm{Ru}_{0.05} \mathrm{Zr}_{1.95} \mathrm{O}_{7}$ (LSRuZ) and $0.5 \% \mathrm{Ru} / \mathrm{Al}_{2} \mathrm{O}_{3}$ catalyst [26]. The superior performance of $0.5 \% \mathrm{Ru} / \mathrm{Al}_{2} \mathrm{O}_{3}$ over LSRuZ suggested kinetically faster happening of RWGS reaction than on LSRuZ. 
Meanwhile, the $\mathrm{CH}_{4}$ conversions for $0.5 \% \mathrm{Ru} / \mathrm{Al}_{2} \mathrm{O}_{3}$ and LSRuZ were $62 \%$ and $58 \%$, respectively at $\mathrm{CH}_{4} / \mathrm{CO}_{2}=$ 2:1. This can be elucidated that higher $\mathrm{CH}_{4}$ decomposition over $0.5 \% \mathrm{Ru} / \mathrm{Al}_{2} \mathrm{O}_{3}$ than $\mathrm{LSRuZ}$ at this feed ratio.

The effects of feed ratios $\left(\mathrm{CH}_{4}: \mathrm{CO}_{2}\right)$ ranged $0.1-1.0$ also investigated by Ayodele et al. (2016) [22]. Maximum $\mathrm{CH}_{4}$ and $\mathrm{CO}_{2}$ conversions of $62.7 \%$ and $82 \%$, respectively, were obtained at feed ratio of 1.0 (highest ratio employed) and reaction temperature of $750^{\circ} \mathrm{C} \mathrm{(Fig.}$ 5). Moreover, the production of syngas was observed to increase with feed ratio, reaching the maximum product yield of $59.9 \%$ and $62.02 \%$ for $\mathrm{H}_{2}$ and $\mathrm{CO}$. Additionally, the effects of $\mathrm{CO}_{2} / \mathrm{CH}_{4}$ ratio (0.5-3) on equilibrium conversions, product compositions and solid carbon was studied by Nikko and Amin (2011) [24]. Meanwhile, $\mathrm{CH}_{4}$ conversion increases with $\mathrm{CO}_{2} / \mathrm{CH}_{4}$ ratio implying the $\mathrm{CO}_{2}$ gas as a soft oxidant has a positive effect on $\mathrm{CH}_{4}$ conversion. When $\mathrm{CO}_{2} / \mathrm{CH}_{4}$ ratios $<1$, the amount of $\mathrm{H}_{2}$ produced enhances within the whole investigated temperature, as $\mathrm{CO}_{2}$ is the limiting reactant and the RWGS reaction cannot simultaneously improve along with partial oxidation of methane $\left(\mathrm{CH}_{4}+1 / 2 \mathrm{O}_{2} \leftrightarrow \mathrm{CO}+\right.$ $2 \mathrm{H}_{2}$ ). Meanwhile, the number of $\mathrm{H}_{2}$ moles produced decreases with increasing $\mathrm{CO}_{2} / \mathrm{CH}_{4}$ ratio from 0.5 to 1 at a specified temperature. The declining trend of $\mathrm{H}_{2}$ either for specified $\mathrm{CO}_{2} / \mathrm{CH}_{4}$ ratios $(>1)$ versus different temperatures or for specified temperature $(>973 \mathrm{~K})$ versus different $\mathrm{CO}_{2} / \mathrm{CH}_{4}$ ratios $(>1)$ are presumably ascribed to RWGS reaction in which $\mathrm{H}_{2}$ produced reacts with $\mathrm{CO}_{2}$ to form water and $\mathrm{CO}$. Generally, $\mathrm{H}_{2}$ production becomes lower with increasing $\mathrm{CO}_{2} / \mathrm{CH}_{4}$ ratio due to $\mathrm{CH}_{4}$ being a more intensive limiting reactant restricted the source of hydrogen atoms.

Fakeeh et al. [41] also found that an increase in $\mathrm{CH}_{4} / \mathrm{CO}_{2}$ ratio $(0.25-2.33)$ over $\mathrm{Ni} / \mathrm{SiO}_{2}$ increased the $\mathrm{CO}_{2}$ conversion, but decreased the $\mathrm{CH}_{4}$ conversion. The higher $\mathrm{CH}_{4}$ conversion than thermodynamic equilibrium suggested the happening of side reaction, $\mathrm{CH}_{4}$ decomposition. When $\mathrm{CH}_{4} / \mathrm{CO}_{2}$ ratio was $>1, \mathrm{CH}_{4}$ conversion increased and was quite similar with the thermodynamic equilibrium. Similar trends also reported by Serrano-Lotina et al. [31], Xu et al. [32], Meshkani et al. [42], and Meshkani and Rezaei [43]. Indeed, high $\mathrm{CH}_{4}$ composition in the reactants facilitates $\mathrm{CH}_{4}$ cracking and coke deposition, resulting in catalyst instability. When the feedstock of $\mathrm{CH}_{4}=\mathrm{CO}_{2}$, the coke removal rate by $\mathrm{CO}_{2}$ is less than that of coke formation by $\mathrm{CH}_{4}$ cracking.

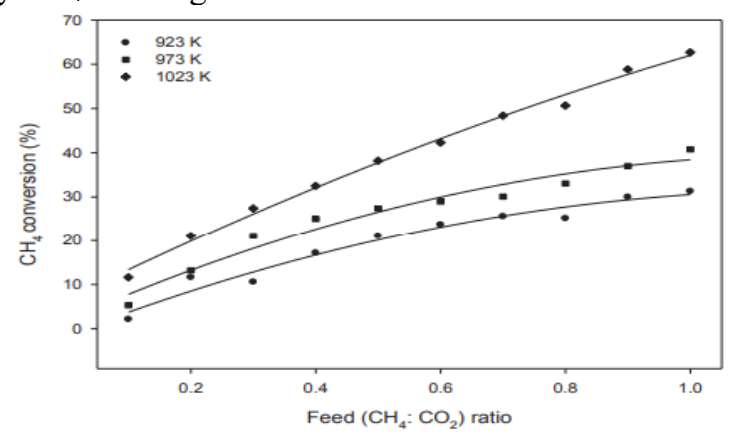

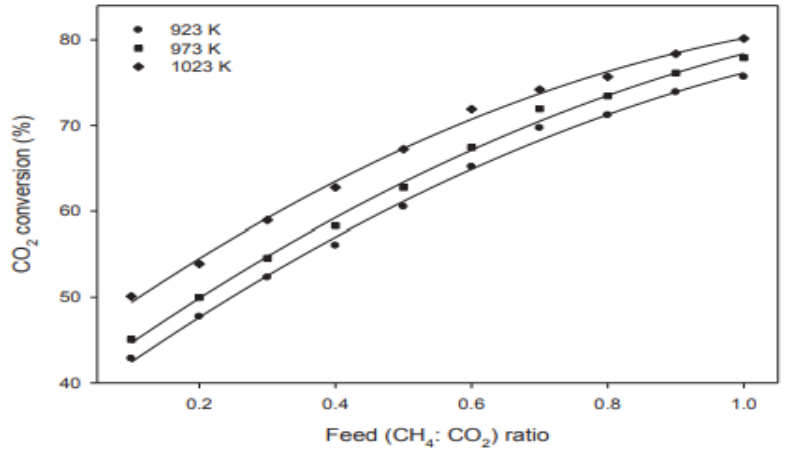

Fig. 5. Conversion of (a) $\mathrm{CH}_{4}$ and (b) $\mathrm{CO}_{2}$ from methane dry reforming over $20 \mathrm{wt} \% \mathrm{Co} / 80 \mathrm{wt} \% \mathrm{Nd}_{2} \mathrm{O}_{3}$ catalyst. Adapted from [22].

In summary, a superabundance of $\mathrm{CO}_{2}$ led to lower $\mathrm{CO}_{2}$ conversion but higher $\mathrm{CH}_{4}$ conversions. At this circumstance, higher quantity of $\mathrm{H}_{2}$ was taken by RWGS reaction, so decreased $\mathrm{H}_{2}$ selectivity. Thus, when $\mathrm{CH}_{4} / \mathrm{CO}_{2}>1, \mathrm{CH}_{4}$ conversion decreased but $\mathrm{H}_{2}$ selectivity higher. From the previous studies, it can be concluded that $\mathrm{CH}_{4} / \mathrm{CO}_{2}$ ratios between 1 and 1.43 seem to be the most optimal feedstock ratio to attain the best catalytic performance with low coke deposition and metal sintering.

Table 3. Influence of $\mathrm{CH}_{4} / \mathrm{CO}_{2}$ ratio on catalytic activity.

\begin{tabular}{|c|c|c|c|c|c|c|}
\hline \multirow[t]{2}{*}{ Catalyst } & \multirow{2}{*}{$\begin{array}{c}\mathrm{T} \\
\left({ }^{\circ} \mathrm{C}\right)\end{array}$} & \multirow{2}{*}{$\begin{array}{c}\mathrm{CH}_{4} / \mathrm{CO}_{2} \\
\text { ratio }\end{array}$} & \multirow{2}{*}{$\begin{array}{c}\mathrm{W} \\
\left(\mathrm{L} \cdot \mathrm{g}^{-}\right. \\
\left.{ }^{1} \mathrm{~h}^{-1}\right)\end{array}$} & \multicolumn{2}{|c|}{$\mathrm{X}(\%)$} & \multirow[t]{2}{*}{ Ref. } \\
\hline & & & & $\mathrm{CO}_{2}$ & $\mathrm{CH}_{4}$ & \\
\hline \multirow{3}{*}{$\begin{array}{l}\mathrm{Ni-Co} / \\
\mathrm{MSN}\end{array}$} & \multirow[t]{3}{*}{750} & 1.0 & \multirow[t]{3}{*}{15} & - & 87 & \multirow[t]{3}{*}{ [19] } \\
\hline & & 3.0 & & - & 85 & \\
\hline & & 5.0 & & - & 83 & \\
\hline \multirow[t]{3}{*}{$\mathrm{SmCoO}_{3}$} & \multirow[t]{3}{*}{750} & 0.5 & \multirow[t]{3}{*}{30} & 90 & 65 & \multirow[t]{3}{*}[40]{} \\
\hline & & 1.0 & & 85 & 85 & \\
\hline & & 2.0 & & 53 & 55 & \\
\hline \multirow{4}{*}{$\begin{array}{c}\mathrm{Pt} / \mathrm{CeO}_{2} / \\
\alpha-\mathrm{Al}_{2} \mathrm{O}_{3}\end{array}$} & \multirow[t]{4}{*}{750} & 0.5 & \multirow[t]{4}{*}{7.2} & 93 & 53 & \multirow[t]{4}{*}[21]{} \\
\hline & & 1.0 & & 75 & 65 & \\
\hline & & 2.0 & & 58 & 85 & \\
\hline & & 3.0 & & 48 & 90 & \\
\hline \multirow{4}{*}{$\begin{array}{c}\mathrm{Co} / \\
\mathrm{Nd}_{2} \mathrm{O}_{3}\end{array}$} & \multirow[t]{4}{*}{750} & 0.4 & \multirow[t]{4}{*}{30} & 63 & 30 & \multirow[t]{4}{*}[22]{} \\
\hline & & 0.6 & & 72 & 40 & \\
\hline & & 0.8 & & 75 & 48 & \\
\hline & & 1.0 & & 78 & 62 & \\
\hline \multirow{3}{*}{$\begin{array}{c}\mathrm{Ru} / \\
\mathrm{Al}_{2} \mathrm{O}_{3}\end{array}$} & \multirow[t]{3}{*}{785} & 0.5 & \multirow[t]{6}{*}{18} & 96 & 99 & {$[26]$} \\
\hline & & 1.0 & & 95 & 96 & \\
\hline & & 2.0 & & 64 & 62 & \\
\hline LSRuZ & 785 & 0.5 & & 60 & 98 & \\
\hline & & 1.0 & & 95 & 95 & \\
\hline & & 2.0 & & 95 & 57 & \\
\hline $\mathrm{Ni} / \mathrm{SiO}_{2}$ & 575 & 0.25 & - & - & 31 & [41] \\
\hline & & 0.67 & & & 45 & \\
\hline & & 1.00 & & & 49 & \\
\hline & & 1.50 & & & 57 & \\
\hline & & 2.33 & & & 65 & \\
\hline & 700 & 0.67 & 21 & FBR & 60 & {$[31]$} \\
\hline Hydro-talcite & & 0.83 & & & 73 & \\
\hline & & 1.00 & & & 81 & \\
\hline & & 1.43 & & & 82 & \\
\hline & & 2.50 & & & 86 & \\
\hline $\mathrm{Ni}-\mathrm{Co} /$ & 800 & 0.33 & 6 & FBR & 59 & {$[32]$} \\
\hline $\mathrm{La}_{2} \mathrm{O}_{3}-\mathrm{Al}_{2} \mathrm{O}_{3}$ & & 0.67 & & & 75 & \\
\hline & & 1.00 & & & 96 & \\
\hline & & 1.50 & & & 100 & \\
\hline & & 3.00 & & & 100 & \\
\hline $\mathrm{Ni} / \mathrm{MgO}$ & 700 & 0.50 & 18 & FBR & 60 & {$[42]$} \\
\hline & & 0.67 & & & 66 & \\
\hline & & 1.00 & & & 77 & \\
\hline & & 2.00 & & & 82 & \\
\hline $\mathrm{Ni} / \mathrm{MgO}$ & 700 & 0.33 & 10 & FBR & 62 & [43] \\
\hline
\end{tabular}




\begin{tabular}{|l|l|l|l|l|l|l|}
\hline & & 0.50 & \multirow{4}{*}{} & & 69 & \multirow{2}{*}{} \\
& & 1.00 & & 84 & \\
& 2.00 & & & 90 & \\
\hline
\end{tabular}

$\mathrm{T}=$ temperature, $\mathrm{W}=\mathrm{WHSV}, \mathrm{X}=$ conversion.

\subsection{WHSV}

Weight hourly space velocity (WHSV) is related to the residence time for the interaction between catalyst particles and the reactants on the catalyst bed. Optimal WHSV can facilitated the reactants' conversions by providing satisfactory catalyst-reactant interaction. Published journals on the effects of weight hourly gas velocity (WHSV) on DRM using distinct catalysts were tabulated in Table 4. Parametric study on the DRM performance over the reactant volumetric flow rate effect in terms of catalyst weight versus reactant flow rate $\left(\mathrm{W} / \mathrm{F}_{0}\right)$ were executed by Chein et al. [39]. In this study, $\mathrm{W}$ is fixed while $\mathrm{F}_{0}$ was varied throughout the investigation. With the increased $\mathrm{W} / \mathrm{F}_{0}$ by decreasing the reactant flow rate, the higher reaction rate was achieved which led to higher reactants conversions. This enhancement was due to the increased residential contact time of the reactants with the catalyst. In addition, the high reaction rate resulted from higher $\mathrm{W} / \mathrm{F}_{0}$, resulted in higher carbon yield as well. Meanwhile, $\mathrm{CH}_{4}$ and $\mathrm{CO}_{2}$ conversions became independent of $\mathrm{W} / \mathrm{F}_{0}$ when operating temperatures are $>1000^{\circ} \mathrm{C}$ and $800^{\circ} \mathrm{C}$, respectively.

Similar finding was also reported by Sidik et al. [19] , that $\mathrm{CH}_{4}$ conversion also increased with the increased in the WHSV until reached the optimal point, the further increment in the WHSV value decreased the $\mathrm{CH}_{4}$ conversion. This was also related to the effect of residence time brought by WHSV, that resulted in the shorter contact time for the interaction between reactants and the catalyst, thus lowering its catalytic activity. Moreover, similar observation was reported by Schwengber et al. (2016) [25] that demonstrated the catalytic reaction tests at different space velocities (WHSV of 15 and $45 \mathrm{~L} \cdot \mathrm{h}^{-1} \cdot \mathrm{g}_{\text {cat }}{ }^{-1}$ ) by using $15 \% \mathrm{Ni} / \mathrm{Al}_{2} \mathrm{O}_{3}$ and $30 \% \mathrm{Ni} / \mathrm{Al}_{2} \mathrm{O}_{3}$ catalyst. From the results acquired, $\mathrm{CH}_{4}$ conversion was also found to be decreased when WHSV increased. Apart from relating with the residence time, the finding can be understood in another way round that larger quantity of catalyst or longer beg length (lower WHSV) in the reaction bed favoured the reactants conversion and product formation [44].

In another studies by $\mathrm{Xu}$ et al. [32] and Meshkani et al. [42] whom adopted $\mathrm{Ni}-\mathrm{Co} / \mathrm{La}_{2} \mathrm{O}_{3}-\mathrm{Al}_{2} \mathrm{O}_{3}$ and $\mathrm{Ni} / \mathrm{MgO}$ catalysts also witnessed the decline trends of the conversions with increasing GHSV. They proposed that high GHSV is beneficial in reducing metallic sintering and increasing the crystallites sizes during the reaction. They further declared that even though high GHSV offers higher contact frequency between the reactants and the catalyst but a shorter residence time, thus lower $\mathrm{CH}_{4}$ and $\mathrm{CO}_{2}$ conversions were resulted. This phenomena were also in agreement with the findings obtained by Meshkani and Rezaei. [43], which also reported the negative effect on conversions upon increasing GHSV.
The effect of gas hour space velocity (GHSV) on the catalytic performance of $\mathrm{Ni} / \mathrm{La}_{2} \mathrm{Zr}_{2} \mathrm{O}_{7}$ and $\mathrm{Ni} /$ hydrotalcite-like precursor catalysts were also studied by le Saché et al. [33] and Serrano-Lotina et al. [36]. Similar findings also observed when a greater extent of activity drop was witnessed after doubling the GHSV; however, the overall conversions achieved were still comparably good especially for $\mathrm{CO}_{2}$. Furthermore, it was also noted that $\mathrm{CH}_{4}$ conversion decreased by a greater extent than $\mathrm{CO}_{2}$, owing to the difficulty in overcoming the relatively stable $\mathrm{C}-\mathrm{H}$ bonds present in $\mathrm{CH}_{4}$ for its activation.

In summary, large WHSV was not favoured for the conversions of reactants and product yield, which can be claimed on the shorter residence time between both catalyst and reactants. Lower WHSV was somehow preferable in enhancing DRM activity which enable a longer contact time for catalyst to activate the reactants' behaviours. At these conditions, mass transfer dominates and kinetic control is the decisive factor when the reactants conversions achieved up to the thermodynamics equilibrium points.

Table 4. Influence of weight hourly space velocity (WHSV) on catalytic activity.

\begin{tabular}{|c|c|c|c|c|c|c|}
\hline \multirow{2}{*}{ Catalyst } & \multirow{2}{*}{$\begin{array}{c}\text { W }\left(\mathrm{L} . \mathrm{g}^{-1}\right. \\
\left.\mathrm{h}^{-1}\right)\end{array}$} & \multirow{2}{*}{$\mathrm{CH}_{4} / \mathrm{CO}_{2}$} & \multirow{2}{*}{$\mathrm{T}\left({ }^{\circ} \mathrm{C}\right)$} & \multicolumn{2}{|c|}{$\mathrm{X}(\%)$} & \multirow[t]{2}{*}{ Ref. } \\
\hline & & & & $\mathrm{CO}_{2}$ & $\mathrm{CH}_{4}$ & \\
\hline \multirow{3}{*}{ Ni-Co/MSN } & 20 & \multirow[t]{3}{*}{1} & \multirow[t]{3}{*}{750} & - & 82 & \multirow[t]{3}{*}{ [19] } \\
\hline & 40 & & & - & 76 & \\
\hline & 60 & & & - & 44 & \\
\hline \multirow{3}{*}{$\begin{array}{c}15 \% \\
\mathrm{Ni} / \mathrm{Al}_{2} \mathrm{O}_{3}\end{array}$} & 15 & \multirow[t]{6}{*}{1} & \multirow[t]{6}{*}{650} & 43 & 85 & \multirow[t]{6}{*}{ [25] } \\
\hline & 30 & & & 55 & 28 & \\
\hline & 45 & & & 52 & 42 & \\
\hline \multirow{3}{*}{$\begin{array}{c}30 \% \\
\mathrm{Ni} / \mathrm{Al}_{2} \mathrm{O}_{3}\end{array}$} & 15 & & & 55 & 62 & \\
\hline & 30 & & & 68 & 5 & \\
\hline & 45 & & & 45 & 28 & \\
\hline \multirow{5}{*}{$\begin{array}{c}\mathrm{Ni}-\mathrm{Co} / \\
\mathrm{La}_{2} \mathrm{O}_{3}-\mathrm{Al}_{2} \mathrm{O}_{3}\end{array}$} & 3 & \multirow[t]{5}{*}{1} & \multirow[t]{5}{*}{800} & 96 & 85 & \multirow[t]{5}{*}[32]{} \\
\hline & 6 & & & 95 & 88 & \\
\hline & 9 & & & 90 & 86 & \\
\hline & 12 & & & 93 & 85 & \\
\hline & 18 & & & 90 & 80 & \\
\hline \multirow{3}{*}{$\begin{array}{c}\mathrm{Ni} / \\
\mathrm{La}_{2} \mathrm{Zr}_{2} \mathrm{O}_{7}\end{array}$} & 15 & \multirow[t]{3}{*}{1} & \multirow[t]{3}{*}{700} & 91 & 87 & \multirow[t]{3}{*}{ [33] } \\
\hline & 30 & & & 90 & 86 & \\
\hline & 60 & & & 75 & 55 & \\
\hline
\end{tabular}

$\mathrm{T}=$ temperature, $\mathrm{W}=\mathrm{WHSV}, \mathrm{X}=$ conversion.

\section{Conclusion}

The great potential of dry reforming of methane (DRM) to be served as energy transformation and storage system that provide alternatives energies is undeniably the most crucial technology for the sake of future chemical industry and environment. The greatest strength of this reaction is the consumption of the two main components of greenhouse gases $\left(\mathrm{CO}_{2}\right.$ and $\left.\mathrm{CH}_{4}\right)$ to generate syngas $\left(\mathrm{H}_{2}+\mathrm{CO}\right)$. Meanwhile, this reaction was prone to catalyst deactivation due to the thermodynamic nature of the reaction impelled coke formation with the happening of several side reactions. Researches on seeking the excellent and efficient catalysts had achieved the desired accomplishment with the Ni-based catalysts are the most promising in term of its application and economic value. Although the nature and morphology of the supports, active metals used or even the promoters adopted affected the operation of DRM, still the operating conditions during DRM are the other issues that result in 
the carbon deposition. High temperature $\left(>750^{\circ} \mathrm{C}\right)$ is favourable for the endothermic DRM reaction, where this temperature will result in minimal of coke deposition. The optimal partial pressures for reactant gases could not be determined specifically as they may vary with different types of catalysts used. It can be concluded that $\mathrm{CH}_{4} / \mathrm{CO}_{2}$ ratios between 1 and 1.43 seem to be the most optimal feedstock ratio to attain the best catalytic performance with low coke deposition and metal sintering. WHSV between $15-30 \mathrm{~L} \cdot \mathrm{h}^{-1} \cdot \mathrm{g}_{\text {cat }}{ }^{-1}$ has been suggested to be able in enhancing DRM activity by enabling an appropriate contact time for catalyst to activate the reactants' behaviours. In short, this review summarized the various operating conditions studied in the previous literature to provide a clear benchmark for the future DRM studies for the sake to realize the commercialization of this technology in the foreseeable future.

\section{Acknowledgement}

The author wants to acknowledge Universiti Teknologi PETRONAS and ICRF grant 015ME0-194 and YUTP grant (0153AA-E75). Support from Ministry of Education Malaysia through $\mathrm{HICoE}$ award to CBBR is duly acknowledged.

\section{References}

[1] J. Estephane, S. Aouad, S. Hany, B. El Khoury, C. Gennequin, H. El Zakhem, J. El Nakat, A. Aboukar"s, E. Abi Aad, Int J Hydrogen Energ 40, 9201-9208 (2015)

[2] Y. Yao, D. Hildebrandt, D. Glasser, X. Liu, Ind Eng Chem Res 49(21), 11061-11066 (2010)

[3] H. D. Setiabudi, C. C. Chong, S. M. Abed, L. P. Teh, S. Y. Chin, J Environ Chem Eng 6(1), 745-753 (2018) [4] B. V. Ayodele, M. R. Khan, C. K. Cheng, J Nat Gas Sci Eng 27, 1016-1023 (2015)

[5] C.C. Chong, N. Abdullah, S.N. Bukhari, N. Ainirazali, L.P. Teh, H.D. Setiabudi, Int J Hydrog. Energ 44(37) 20815-20825 (2018)

[6] S. Y. Foo, C. K. Cheng, T.-H. Nguyen, A. A. Adesina, Catal Today 2011, 164(1), 221-226

[7] C.C. Chong, S.N. Bukhari, Y.W. Cheng, H.D. Setiabudi, A.A. Jalil, C. Phalakornkule, Appl Catal A 584, 117174. (2019)

[8] O. Omoregbe, H. T. Danh, C. Nguyen-Huy, H. D. Setiabudi, S. Z. Abidin, Q. D. Truong, D.-V. N. Vo, Int J Hydrogen Energ 42(16), 11283-11294 (2017)

[9] M. Usman, W. M. A. Wan Daud, H. F. Abbas, Renew Sustain Energy Rev 45, 710-744. (2015)

[10] S. Arora, R. Prasad, RSC Adv 6 108668-108688. (2016)

[11] W.-J. Jang, J.-O. Shim, H.-M. Kim, S.-Y. Yoo, H.-S. Roh, Catal. Today 324,15-26 (2019)

[12] J.-M. Lavoie, Frontiers in Chemistry 2 (2014).

[13] N.A.K. Aramouni, J.G. Touma, B.A. Tarboush, J. Zeaiter, M.N. Ahmad, Renew Sust Energ Rev 82, 2570-2585 (2018)

[14] M.A.A. Aziz, H.D. Setiabudi, L.P. Teh, N.H.R. Annuar, A.A. Jalil, J Taiwan Inst.Chem E 101, 139-158 (2019)

[15] Y.W. Cheng, Z.S. Lee, C.C. Chong, M.R. Khan, C.K. Cheng, K.H. Ng, S.S. Hossain, Int J Hydrogen Energ, 44(37), 20711-20724 (2018).

[16] M.C.J. Bradford, M.A. Vannice, Catal Rev 41, 1-42. (1999)
[17] C.C. Chong, L.P. Teh, H.D. Setiabudi, Mater Today Energ 12 (2019) 408-417.

[18] P. Cao, S. Adegbite, T. Wu, Energ Procedia, 105 18641869 (2017)

[19] S. M. Sidik, S. Triwahyono, A. A. Jalil, Z. A. Majid, N. Salamun, N. B. Talib, T. A. T. Abdullah, Chem Eng J 295, 110. (2016)

[20] U. Izquierdo, V. L. Barrio, J. Requies, J. F. Cambra, M. B. Güemez, P. L. Arias, Int J Hydrogen Energ 38(18), 7623-7631. (2013)

[21] X. Zhang, C. S.-M. Lee, D. M. P. Mingos, D. O. Hayward, Catal Lett 88(3), 129-139 (2003)

[22] B. V. Ayodele, S. S. Hossain, S. S. Lam, O. U. Osazuwa, M. R. Khan, C. K. Cheng, J Nat Gas Sci Eng 34, 873-885 (2016)

[23] M. Khavarian, A. Mohamed, Nanoparticles Mater Sci Forum 756, 182-189 (2013)

[24] M. K. Nikoo, N. A. S. Amin, Fuel Process Technol 92(3), 678-691 (2011)

[25] C. A. Schwengber, F. A. da Silva, R. A. Schaffner, N. R. C. Fernandes-Machado, R. J. Ferracin, V. R. Bach, H. J. Alves, J Environ Chem Eng 4(3), 3688-3695 (2016)

[26] S. Gaur, D. Pakhare, H. Wu, D. J. Haynes, J. J. Spivey, Energ Fuels 26(4), 1989-1998. (2012)

[27] D. Takami, Y. Ito, S. Kawaharasaki, A. Yamamoto, H. Yoshida, Sustain Energy Fuels 3, 2968-2971 (2019)

[28] B. Al-swai, N. Osman, B. Abdullah, AIP Conference Proceedings 1891(1):020028 (2017)

[29] F. Aldoghachi, A. Islam, Z. Zainal, M. Saiman, Z. Embong, Y.H. Taufiq-Yap, PLOS ONE 11, 0145862 (2016)

[30] G. Souza, N. Marcilio, O. Perez-Lopez, Mater Res 17 1047-1055 (2014)

[31] A. Serrano Lotina, L. Daza, Int J Hydrogen Energ 39, 4089 (2013)

[32] J. Xu, W. Zhou, Z. Li, J. Wang, J. Ma, Int J Hydrogen Energ 35, 13013-13020 (2010)

[33] E. le Saché, L. Pastor-Pérez, D. Watson, A. SepúlvedaEscribano, T.R. Reina, Appl Catal B-Environ 236, 458-465 (2018)

[34] C.C. Chong, Y.W. Cheng, M.B. Bahari, L.P. Teh, S.Z. Abidin, H.D. Setiabudi, Int J Hydrogen Energ (2020).

[35] C.C. Chong, H.D. Setiabudi, A.A. Jalil, Int J Hydrogen Energ 45, 18533-18548 (2020)

[36] A. Serrano-Lotina, L. Daza, Int J Hydrogen Energ 39, 4089-4094 (2014)

[37] C.C. Chong, Y.W. Cheng, H.D. Setiabudi, N. Ainirazali, D.-V.N. Vo, B. Abdullah, Int J Hydrogen Energ 45, 8507-8525 (2020)

[38] B.V. Ayodele, M.R. Khan, C.K. Cheng, J Nat Gas Sci Eng 27(2), 1016-1023 (2015)

[39] R.Y. Chein, W.H. Hsu, C.T. Yu, Int J Hydrogen Energ 42, 14485-14500 (2017)

[40] O.U. Osazuwa, C.K. Cheng, Malay J Catal 2 ,12-17 (2017)

[41] A. Fakeeha, A. Alfatesh, M. Soliman, A. Ibrahim, 16th World Hydrogen Energy Conference 1, 245-256 (2006)

[42] F. Meshkani, M. Rezaei, M. Andache, J Ind Eng Chem, 20,1251-1260 (2014)

[43] F. Meshkani, M. Rezaei, J Nat Gas Chem 20, 198-203 (2011)

[44] N. Rahemi, M. Haghighi, A.A. Babaluo, S. Allahyari, M.F. Jafari, Energy Convers. Manag 84, 50-59 (2014) 